\title{
Impacts of land use and planning on island ecosystem service values: a case study of Dinghai District on Zhoushan Archipelago, China
}

\author{
Xiaoyun Shao ${ }^{1}$, Changwei Jing ${ }^{2^{*}}$, Jiaguo Qi ${ }^{*^{*}}$, Jingang Jiang ${ }^{1}$, Qiankun Liu ${ }^{1}$ and Xiumin Cai ${ }^{1}$
}

\begin{abstract}
Recently designated as a new special economic zone in China, Zhoushan Archipelago is going through a rapid land use change that is expected to have significant impacts on ecosystem services. However, there is no baseline of ecosystem service value (ESV) of the Zhoushan Archipelago up to date, making it impossible to assess any impacts of land use changes. In this study, we adopted the concept of "equivalent value per unit area of ecosystem services in China" and computed the ESV for 2006, 2012, and 2020 of a representative district, Dinghai, on the Zhoushan Archipelago. We then analyzed the spatial and temporal patterns of land use changes and their impacts on ESV. The results indicated that the ESV of Dinghai District declined by $59.3 \mathrm{M}$ Chinese yuan ( $\$ 9.5 \mathrm{M}$ US dollars) from 2006 to 2012 and would further decrease by an additional 30.9 M yuan ( $\$ 5$ M US dollars) by 2020 according to its planned land uses. These declines in ESV were primarily due to increases in buildup areas and losses in wetland, farmland, and water areas. The results imply that more attention should be paid to controlling urban growth and protecting coastal wetlands in order to preserve valuable ecosystem services of the Archipelago.
\end{abstract}

Keywords: Island ecosystems, Ecosystem service value, Land use, Zhoushan Archipelago

\section{Introduction}

Assessing ecosystem service values (ESV) is on the frontier of international research. It integrates the disciplines of ecology, economics, sociology, geography, and others (e.g., Speziale and Geneletti 2014 and Wang et al. 2015). Its concept was first introduced by Westman (1977) and subsequently modified by Daily (1977), Costanza et al. (1997b)), and Xie et al. (2001). These studies asserted that the structure, process, and function of ecosystems directly or indirectly provide life support (raw materials, etc.) and services (habitat, etc.), including ecological services necessary to human life and biodiversity.

Land use directly affects ecosystem services through interactions between ecological processes and human activities (e.g., Zhao et al. 2000 and Zhou et al. 2004). By

\footnotetext{
* Correspondence: changweij@zju.edu.cn; jacobchee@zju.edu.cn ${ }^{2}$ Zhejiang Provincial Key Laboratory of Urban Wetland and Regional Change, Hangzhou 311121, China

${ }^{1}$ Institute of Island and Coastal Ecosystems, Ocean College, Zhejiang University, Zhoushan 316021, China
}

changing the types of land cover, land use can affect the physical structure, ecological process, and function of an ecosystem. Therefore, one direct approach to estimating ESV is based on land use, as it reveals the ecological significance of ecosystem service value from the aspects of human activities and management. Previous studies have made extensive and in-depth efforts to quantify ESV across spatial and temporal scales (Costanza et al. 1997a; Mann et al. 2013; Pattanayak 2004; Turner et al. 2000), where ESV were assigned according to land use types based on, for example, expert surveys on the perceived values of different land uses and land cover types (e.g., Xie et al. 2008).

Most of these previous studies focused on terrestrial ecosystems. Few have paid attention to ecosystem services and their value for island ecosystems (Moberg and Rönnbäck 2003; Kumar et al. 2008; Brenner et al. 2010; Badola et al. 2012). Islands are defined as "lands isolated by surrounding water and with a high proportion of coast to hinterland" (Millennium Ecosystem Assessment 
2003). They have characteristics of both land and aquatic systems but are unique in many ways. Due to the special geographical environment, island ecosystems are very fragile and particularly vulnerable to disturbances (e.g., Shi et al. 2009). It has been speculated that rapid developments on islands may prove disastrous for valuable ecosystem services. However, to date, there is no existing baseline ESV of island ecosystems against which the impacts of land use change could be assessed.

As China's first prefecture-level island city, Zhoushan is undergoing rapid land use change. This is the result of its designation in 2011 as a new, special economic zone by the State Council of China's Central Government, the fourth state-level economic reform pioneer zone after Pudong District in Shanghai, Binhai District in Tianjin, and Liangjiang District in Chongqing. How these ongoing land use changes affect the island's ESV remains unclear. Therefore, it is of great importance to evaluate the ESV of Zhoushan Archipelago to gain a better understanding of its changing trajectory and to improve land use planning to ensure sustainable long-term development. To this extent, limited research has been conducted to assess ESV of island ecosystems (Zhao et al. 2016 and Zhao et al. 2014) using, for example, land use information derived from Landsat-type images. Due to its complexity and spatial variability, a better spatial resolution analysis of ESV is needed in order to better understand the consequences of land use planning on ESV. In this study, we used high-resolution land use data obtained from the Zhoushan Land Department to capture the island's spatial variability and geographic characteristics for improved ESV estimation and analysis. We chose to focus on the largest district, Dinghai, on the Zhoushan Archipelago where the most rapid changes in land use have occurred since 2006.

The objective of this research is simply to assess spatio-temporal changes in ecosystem services values resulting from land use changes in the past and in the future. The questions to be addressed are to what extent have the land use changes on Zhoushan Archipelago affected its ESV from 2006 to 2012 and what are their future trajectories for 2020? The analyses of the dynamic spatial and temporal changes in ESV could shed some light on how land use change and land use planning could impact ecosystem service values of island ecosystems, thus providing a better understanding of the ecological implications of land use changes on islands.

\section{Methods}

\section{Study area}

Located at the intersection of the Yangtze River Estuary and Hangzhou Bay of China, Dinghai District (lat. $29^{\circ}$ $55^{\prime} \mathrm{N}-30^{\circ} 15^{\prime} \mathrm{N}$, long. $\left.121^{\circ} 38^{\prime} \mathrm{E}-122^{\circ} 15^{\prime} \mathrm{E}\right)$ is the economic and political center of the Zhoushan Archipelago
(Fig. 1). It consists of 142 islands and covers a total of $1444 \mathrm{~km}^{2}$ land area. Surrounded by the East China Sea, Dinghai District has a monsoon subtropical marine climate with a mean annual temperature of about $17{ }^{\circ} \mathrm{C}$ and an annual rainfall of approximately $1400 \mathrm{~mm}$. Characterized by a mild climate, Dinghai District is biologically rich and highly suitable for agriculture and fisheries production. The district is hilly and thus quite spatially heterogeneous in land use and land cover.

Dinghai District has experienced rapid economic development and urbanization over the past three decades. Its gross domestic product (GDP) increased from 13.95 billion Chinese yuan in 2006 to 45.02 billion Chinese yuan in 2015. During this same time period, its land use changed significantly (Chen et al. 2009).

\section{Data description}

The data used in this study include grain yield, GDP, tourist number, population, national grain purchase price, urban green space rate, and land use data (Table 1) from a variety of data sources, including the Dinghai District Bureau of Statistics, China Grain Yearbook, Zhoushan City Statistics, and the Zhoushan Land Department. Data on land use was obtained from the Zhoushan Land Department and was initially in vector format with detailed land use class information (Table 2). The 2006 land use data was an outcome of the Second National Land Survey in China carried out in 2005-2006, which included land use types, location, extent, area, and distribution. The procedure was in accordance with standard land survey techniques, using a combination of orthophotos and satellite images obtained from a variety of sources including Landsat, SPOT, and Chinese satellites. The survey was carried out at the county level to derive land use maps at a 1:10,000 scale. The land use data from 2012 was the outcome of the Annual Land Use Change Survey, carried out by the Zhoushan Land Department using the same procedure as the Second National Land Survey above. The 2020 data was acquired from the Zhoushan Land Department's Land Use Planning.

Due to the administrative boundary changes that have occurred over the past two decades, this study focused on the common geographic area, or overlap areas, of the Dinghai District to compare ESV across time periods from 2006 to 2012 and to determine the changes expected by 2020. Furthermore, according to the characteristics of Dinghai District, land use types were divided into eight classes: farmland, orchard, forest, grassland, water, construction land, tidal marsh, and others (Table 2).

\section{Land use change analysis}

The total area of each of the eight land use classes was calculated from land use vector maps for 2006 and 2012. 


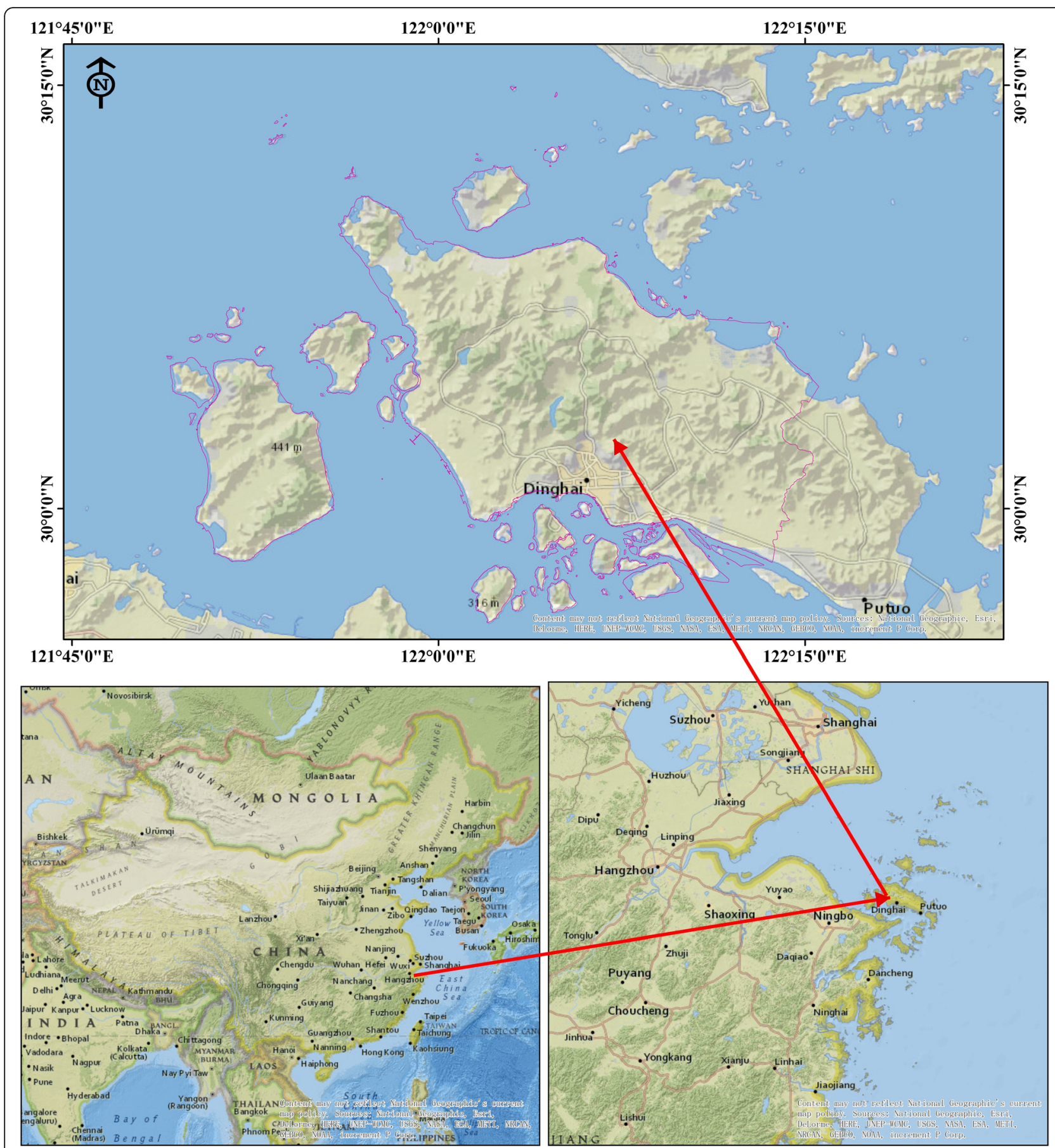

Fig. 1 The study area of Dinghai District in the Zhoushan Archipelago, Zhejiang Province, China

Table 1 Socioeconomic variables and data sources

\begin{tabular}{ll}
\hline Data & Data sources \\
\hline $\begin{array}{l}\text { Grain yield, GDP, tourist } \\
\text { number, and population }\end{array}$ & Dinghai District Bureau of Statistics \\
National grain purchase price & China Grain Yearbook (2014) \\
Urban green space rate & Zhoushan Municipal Bureau of Statistics \\
Land use data & Zhoushan Land Department \\
\hline
\end{tabular}

This allowed us to quantify land use changes using the single land use type dynamic index (Lc). Lc refers to the quantity of change for a specific land use type over a specific time period. It is a quantitative indicator of the land use change rate and has a positive effect on the forecasting of future land use change. The equation to calculate a single land use type dynamic index (Liu et al. 2002) is given as: 
Table 2 Land use classes

\begin{tabular}{ll}
\hline Land use & Classes \\
\hline Farmland & Croplands (upland and paddy included) \\
Orchards & Fruit trees and berries \\
Forest & Natural forest and plantations \\
Grassland & Grassland \\
Water & Reservoir, pond, river \\
Construction land & City, towns, villages, agricultural facilities, \\
& and highways \\
Tidal marsh & Marshes in coastal zones \\
Others & Mining, salt extraction facilities, scenic \\
& spots, and unused land \\
\hline
\end{tabular}

$$
L_{c}=\frac{U_{b}-U_{a}}{U_{a}} \times \frac{1}{T} \times 100 \%
$$

where $L_{\mathrm{c}}$ represents the dynamic index of a certain land use type, $U_{a}$ and $U_{b}$ are the areas of land use types at the beginning $\left(U_{a}\right)$ and end $\left(U_{b}\right)$ of the study period, respectively, and $T$ refers to the study period (years).

\section{Ecosystem service values}

We made some further adjustments to adapt the equivalent ecosystems proposed by Xie et al. (2008) to our study area (Tables 3 and 4). First, the construction land category in our study included some urban green space. According to $\mathrm{Hu}$ (2013), the ESV of construction land is obtained by that of urban green space multiplied by the percentage of green space within the urban land, or $34.83 \%$ for the Dinghai District. Second, in accordance with Feng et al. (2014) and Xu et al. (2008), we adjusted the orchard and other land use type's coefficients as shown in Table 4. Finally, based on the fact that there was no ideal grassland in the study area, we adjusted the grassland coefficient values to be half of that of mainland grassland. The tidal marsh belonged to the coastal wetland, and therefore, its coefficient was set for a wetland as in Xie et al. (2008).
Table 4 Adjusted ecosystem service value coefficient (VC)

\begin{tabular}{|c|c|c|}
\hline Value coefficient & Coefficient adjustments $^{\mathrm{a}}$ & Reference \\
\hline$V C_{\text {farnland }}$ & $V C_{\text {farmland }}$ & This study \\
\hline$V C_{\text {orchard }}$ & $\left(V C_{\text {forest }}+V C_{\text {farmland }}\right) / 2$ & (Feng et al. 2014) \\
\hline$V C_{\text {forest }}$ & $V C_{\text {forest }}$ & This study \\
\hline$V C_{\text {grassland }}$ & $V C_{\text {grassland }} / 2$ & This study \\
\hline$V C_{\text {water }}$ & $V C_{\text {river/lake }}$ & This study \\
\hline$V C_{\text {construction land }}$ & $\begin{array}{l}\left(0.5 \mathrm{~V} C_{\text {forest }}+0.4 \mathrm{~V} C_{\text {grassland }}\right. \\
\left.+0.1 \mathrm{~V} C_{\text {river/lake }}\right)^{\mathrm{a}} 0.3483\end{array}$ & (HU et al. 2013) \\
\hline$V C_{\text {others }}$ & $\left(V C_{\text {grassland }}+V C_{\text {desert }}\right) / 2$ & (Xu et al. 2008) \\
\hline $\mathrm{VC}_{\text {tidal marsh }}$ & $V C_{\text {wetland }}$ & This study \\
\hline
\end{tabular}

Based on the parameters proposed by Costanza et al. (1997), Xie et al. (2008) extracted the "equivalent value per unit area of ecosystem services in China" by surveying more than 200 Chinese ecologists. The factor of average natural food production of farmland without labor input per hectare per year was set at 1.0, and other coefficients were adjusted accordingly according to its land uses. By localizing natural grain production, the equivalent value factor was applied to different regions in China (Xie et al. 2003). In this approach, the natural ecosystem is proposed to represent one seventh of the actual food production. From 2006 to 2015, the average actual grain production in Dinghai district was $4826 \mathrm{~kg} /$ ha, and the average price for grain (mainly composed of paddy, wheat, maize) was 2.1 Chinese yuan $/ \mathrm{kg}(1$ Chinese yuan $=\$ 0.16$ USD) (Wang et al. 2014). One equivalent factor of the ESV is therefore 1447.8 Chinese yuan $(1.0 * 4826 * 2.1 / 7)$. The ESV of each land use type in Dinghai District per unit area was then adjusted and tabulated as shown in Table 5.

\section{Calculation of ecosystem service values}

The ESV of Dinghai District for each of the three time periods (i.e., 2006, 2012, and the planned year 2020) was

Table 3 Equivalent ecosystem service value per unit area in China based on the research by Xie et al. (2008)

\begin{tabular}{|c|c|c|c|c|c|c|c|}
\hline & & Forest & Grassland & Farmland & Wetland & Water & Desert \\
\hline \multirow[t]{2}{*}{ Providing services } & Food production & 0.33 & 0.43 & 1.00 & 0.36 & 0.53 & 0.02 \\
\hline & Raw material & 2.98 & 0.36 & 0.39 & 0.24 & 0.35 & 0.04 \\
\hline \multirow[t]{4}{*}{ Regulating services } & Gas regulation & 4.32 & 1.50 & 0.72 & 2.41 & 0.51 & 0.06 \\
\hline & Climate regulation & 4.07 & 1.56 & 0.97 & 13.55 & 2.06 & 0.13 \\
\hline & Hydrological regulation & 4.09 & 1.52 & 0.77 & 13.44 & 18.77 & 0.07 \\
\hline & Waste treatment & 1.72 & 1.32 & 1.39 & 14.40 & 14.85 & 0.26 \\
\hline \multirow[t]{2}{*}{ Supporting services } & Soil maintenance & 4.02 & 2.24 & 1.47 & 1.99 & 0.41 & 0.17 \\
\hline & Biodiversity maintenance & 4.51 & 1.87 & 1.02 & 3.69 & 3.43 & 0.40 \\
\hline Cultural services & Providing aesthetic landscape & 2.08 & 0.87 & 0.17 & 4.69 & 4.44 & 0.24 \\
\hline Total & & 28.12 & 11.67 & 7.9 & 54.77 & 45.35 & 1.39 \\
\hline
\end{tabular}


Table 5 Adjusted ESV per unit area of different land use in Dinghai District (Chinese Yuan*ha ${ }^{-1 *} \mathrm{y}^{-1}$ )

\begin{tabular}{llrrrrrrrr}
\hline & & Farmland & Orchard & Forest & Grassland & Water & Construction land & Others & Tidal marsh \\
\hline Providing services & Food production & 1447.8 & 962.8 & 477.8 & 311.3 & 767.3 & 10.1 & 325.8 & 521.2 \\
& Raw material & 564.6 & 2439.5 & 4314.4 & 260.6 & 506.7 & 20.2 & 289.6 & 347.5 \\
\multirow{2}{*}{ Regulating services } & Gas regulation & 1042.4 & 3648.5 & 6254.5 & 1085.9 & 738.4 & 1417.5 & 1129.3 & 3489.2 \\
& Climate regulation & 1404.4 & 3648.5 & 5892.5 & 1129.3 & 2982.5 & 1444.7 & 1223.4 & 19617.7 \\
& Hydrological regulation & 1114.8 & 3518.2 & 5921.5 & 1100.3 & 27175.2 & 2284.3 & 1151.0 & 19458.4 \\
& Waste treatment & 2012.4 & 2251.3 & 2490.2 & 955.5 & 21499.8 & 1448.8 & 1143.8 & 20848.3 \\
Supporting services & Soil maintenance & 2128.3 & 3974.2 & 5820.2 & 1621.5 & 593.6 & 1486.1 & 1744.6 & 2881.1 \\
& Biodiversity maintenance & 1476.8 & 4003.2 & 6529.6 & 1353.7 & 4966.0 & 1687.3 & 1643.3 & 5342.4 \\
Cultural services & Providing aesthetic landscape & 246.1 & 1628.8 & 3011.4 & 1353.7 & 6428.2 & 2239.0 & 803.5 & 6790.2 \\
\hline
\end{tabular}

determined using the method described below (Costanza et al. 1997b), which has been applied and proven feasible in previous studies (e.g., Li et al. 2010; Estoque and Murayama 2013).

$$
\begin{aligned}
& \mathrm{ESV}_{k}=\sum_{f} A_{k} \mathrm{VC}_{k f} \\
& \mathrm{ESV}_{f}=\sum_{k} A_{k} \mathrm{VC}_{k f} \\
& \mathrm{ESV}=\sum_{k} \sum_{f} A_{k} \mathrm{VC}_{k f}
\end{aligned}
$$

where $\mathrm{ESV}_{k}, \mathrm{ESV}_{f}$, and ESV refer to the ESV of land use type $k$, service function $f$, and the total ecosystem services value, respectively, (in the unit of Chinese yuan). $A_{k}$ is the area of land use type $k(\mathrm{ha})$, and $\mathrm{VC}_{k f}$ is the value coefficient for land use type $k$ with ecological service function type $f$.

Since the land use types used in the original studies did not exactly match the land use types of Dinghai District, there were uncertainties in the value coefficients. Thus, additional sensitivity analysis was needed to verify the changes in the ESV for a given change in coefficient. In this study, the coefficient of sensitivity (CS) was calculated using the standard economic concept of elasticity as provided below (Kreuter et al. 2001):

$$
\mathrm{CS}=\frac{\mathrm{ESV}_{j}-\mathrm{ESV}_{i} / \mathrm{ESV}_{i}}{\mathrm{VC}_{j k}-\mathrm{VC}_{i k} / \mathrm{VC}_{i k}}
$$

where ESV refers to the estimated ecosystem service values, VC refers to the value coefficient, $i$ and $j$ represent the initial and the adjusted values, and $k$ is the land use type. If $\mathrm{CS}>1$, then the estimated ecosystem value is elastic with respect to that coefficient, but if $C S<1$, then the estimated ecosystem value is considered to be inelastic. The greater the proportional change in ESV relative to the proportional change in the valuation coefficient, the more critical it is to use an accurate ecosystem value coefficient.

\section{Results}

\section{Land use changes}

Comparing the land use data of 2006, 2012, and the planned 2020 (Fig. 2; Table 6), there was an obvious change in land use from 2006 to 2012. It was closely related to the setting up of the Zhoushan Archipelago as a new special economic zone and the rapid development and urbanization in the Dinghai District. From 2006 to 2012, the amount of construction land represented the largest increase, while the area of farmland saw the largest decrease. Due to the fact that the total amount of farmland was high, its dynamic index was not very large. The area of tidal marsh also decreased, and most of the farmland and tidal marshes were transformed into construction land. The total area of grassland was reduced, and the absolute value of its dynamic index was the largest among all land use types because of the relatively small abundance. The "others" land use category rose with the exception of the total area of orchard and water surface areas, which saw decreases. Finally, the amount of forest increased and was the minimum absolute value of the dynamic index. This is mainly because it represented the largest proportion of land use in the study area (nearly $41 \%$ ) and was also a stable land use type.

The pie chart of land use transition in our study area is shown in Figs. 3 and 4. Most of the lost farmland was converted into construction land (Fig. 3) Similarly, the total water areas, comprised of tidal marsh and others, transitioned to urban lands. This was a result of growing urban sprawl and the fast development of the economy. Meanwhile, most of the orchards and grasslands were changed to forests, which was closely related to the policies of returning farmland to forest, and grassland reclamation. During the period of 2006 to the planning year 2020, we forecasted that more farmland would be transformed into construction land, as would the water and forest areas.

In general from 2006 to 2012, the total area of construction land, forest, and the 'other's category increased, while the total area of farmland, orchard, water, 

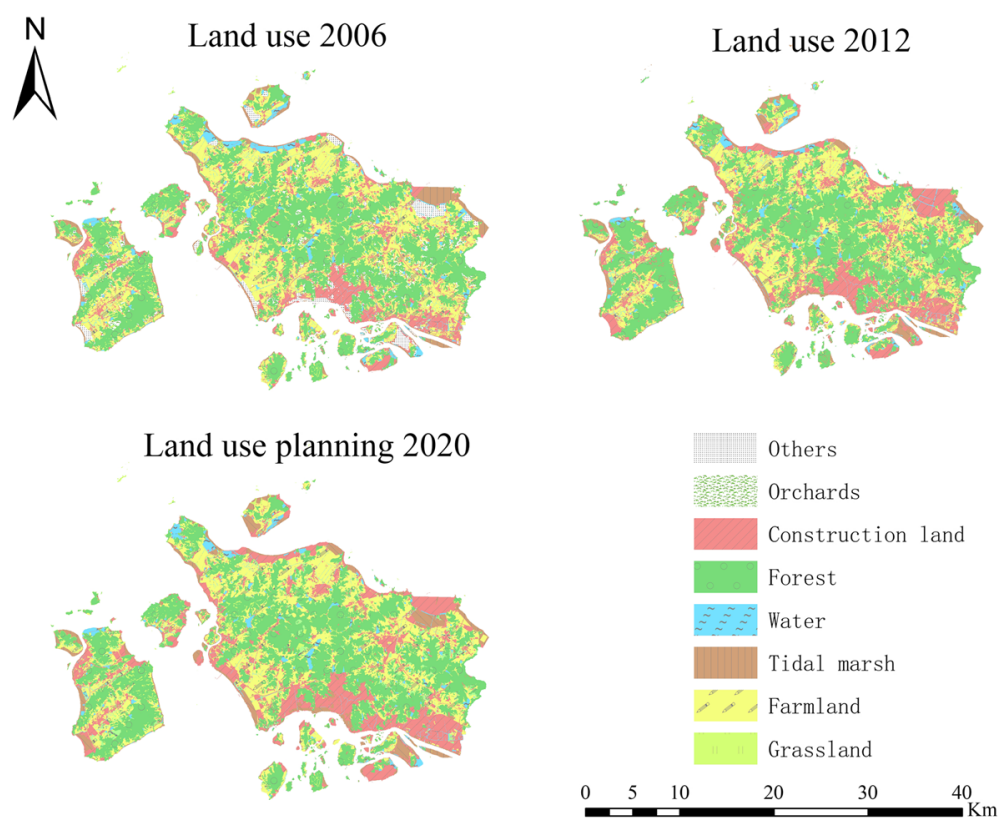

Fig. 2 Land use maps of Dinghai District in 2006, 2012, and 2020

grassland, and tidal marsh decreased, with construction land as the most rapidly expanding land use type. From 2006 to the planned year 2020, the total area of construction land and orchards increased while others land types decreased. Among the land types, the construction land grew the fastest while farmland area was reduced the most. In terms of the dominant land use and land cover type, the total area of forest was the largest, accounting for over $40 \%$ of the study area, followed by farmland and construction land, while grassland was the smallest.

\section{Changes in ecosystem service values}

The ESV of each land use type (Table 7) and ecosystem service function (Table 8) were calculated using the value coefficients (Table 5) and the equations (Eqs. 2-4) as detailed by Costanza (1997). As shown in Table 9, the
ESV of 2006, 2012, and the planned year 2020 were 1642.1, 1582.8, and 1552.0 million Chinese yuan, respectively. Compared to 2006, the ESV in 2012 declined by 59.3 million Chinese yuan, and that of the planned year 2020 declined by 90.2 million Chinese Yuan. In terms of land use type, more than 55\% of the total ESV values were in the forest, followed by farmland, water and tidal marsh, and grasslands. This confirms that forests play a very important role in ecological services.

From 2006 to 2012, the ESV values of tidal marsh and water were greatly reduced, whereas those of construction land significantly increased. This was primarily because of the reduction in the total area of tidal marsh and water areas, as well as the fact that their value coefficients were relatively large even though the construction land area expanded the most during this time period. In 2012, construction land comprised $18.3 \%$ of

Table 6 Changes in total land use area and dynamic index (DI)

\begin{tabular}{|c|c|c|c|c|c|c|c|c|c|}
\hline \multirow[t]{2}{*}{ Land use } & \multirow{2}{*}{$\begin{array}{l}2006 \\
\text { Area (ha) }\end{array}$} & \multirow{2}{*}{$\begin{array}{l}2012 \\
\text { Area (ha) }\end{array}$} & \multirow{2}{*}{$\begin{array}{l}2020 \\
\text { Area (ha) }\end{array}$} & \multicolumn{2}{|c|}{ 2006-2012 } & \multicolumn{2}{|l|}{$2012-2020$} & \multicolumn{2}{|c|}{$2006-2020$} \\
\hline & & & & Area (ha) & DI (\%) & Area (ha) & DI (\%) & Area (ha) & DI (\%) \\
\hline Farmland & 16147.76 & 14399.99 & 14611.77 & -1747.76 & -1.80 & 211.78 & 0.18 & -1535.99 & -0.68 \\
\hline Orchard & 1074.99 & 1051.25 & 1392.08 & -23.75 & -0.37 & 340.83 & 4.05 & 317.09 & 2.11 \\
\hline Forest & 23309.50 & 23696.07 & 22651.10 & 386.57 & 0.28 & -1044.97 & -0.55 & -658.40 & -0.20 \\
\hline Grassland & 1079.19 & 539.71 & 976.77 & -539.48 & -8.33 & 437.06 & 10.12 & -102.42 & -0.68 \\
\hline Water & 2581.26 & 2235.89 & 2042.89 & -345.37 & -2.23 & -193.00 & -1.08 & -538.37 & -1.49 \\
\hline Construction & 7358.99 & 10247.90 & 10606.86 & 2888.91 & 6.54 & 358.96 & 0.44 & 3247.87 & 3.15 \\
\hline Others & 1962.47 & 2141.24 & 1947.97 & 178.77 & 1.52 & -193.27 & -1.13 & -14.50 & -0.05 \\
\hline Tidal marsh & 2445.62 & 1647.73 & 1730.34 & -797.89 & -5.44 & 82.62 & 0.63 & -715.28 & -2.09 \\
\hline
\end{tabular}




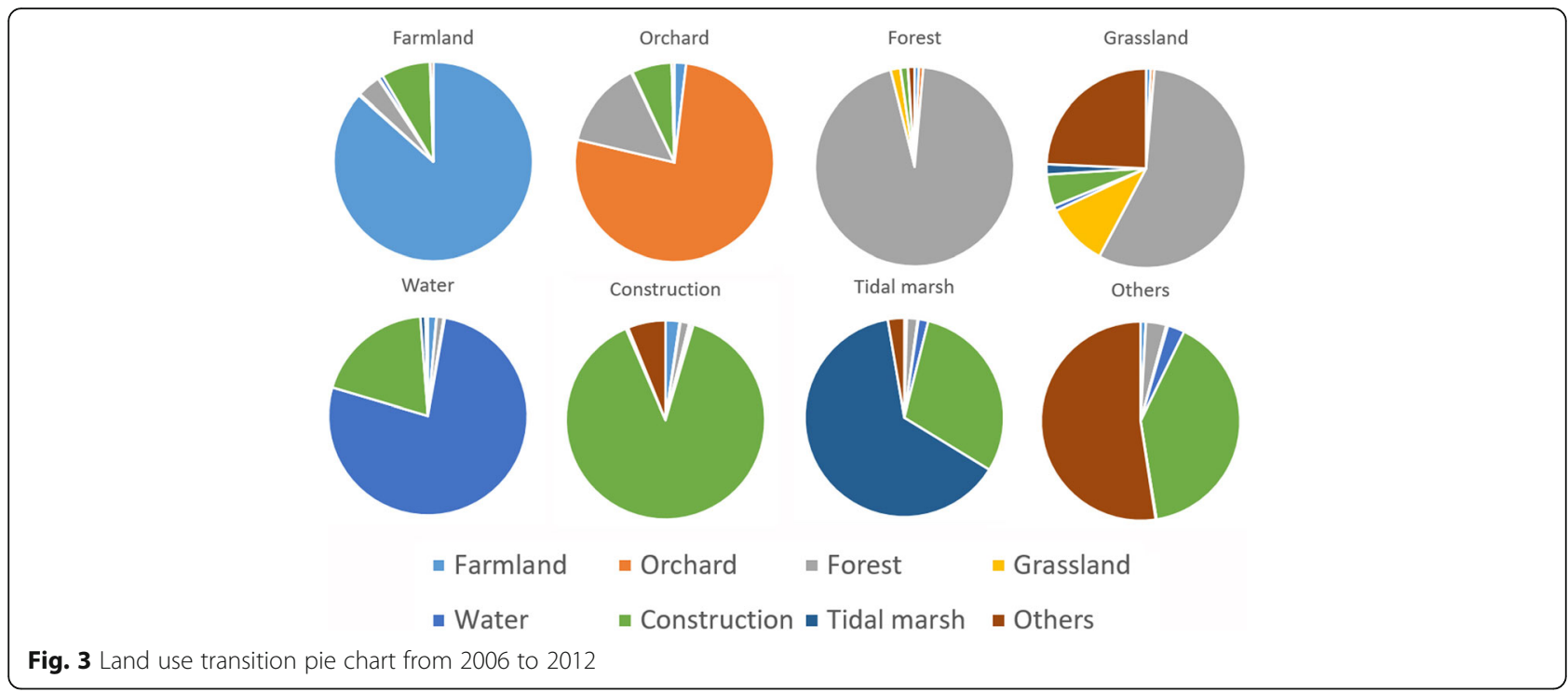

all land use types, yet its ESV was only $7.8 \%$. This means that the total ESV would decrease with the growth of construction land. From 2006 to the planned year 2020, the ESV of the construction and orchard land use types increased while others were all reduced.

In respect to the ecosystem functions listed in Table 8 , the primary functions were hydrological regulation, maintaining biodiversity, waste treatment, and climate regulation, which accounted for more than $55 \%$ of total ESV. Food production's ESV values were the lowest among all land uses. This is primarily due to the large value coefficients of water, tidal marsh, and forest, which play important roles in hydrological regulation, waste-water treatment, and climate regulation.

\section{Spatial distribution of ESV}

The spatial distribution of the ESV of the Dinghai District in 2006, 2012, and the planned year 2020 is illustrated in Fig. 5. Areas with high service values over 40,000 Chinese yuan per ha per year were mainly located in the center and coastal zones of the island, even though the forest, water, and tidal marsh were the dominant land use types. Areas with service values of 20,000-40,000 Chinese yuan per ha per year were scattered throughout the District, as seen for the orchard land use type. Areas with low service values less than 10,000 Chinese yuan per ha per year, such as the construction and "others" land use categories, were located near the coastlines. This is indicative of urbanization and ocean reclamation.

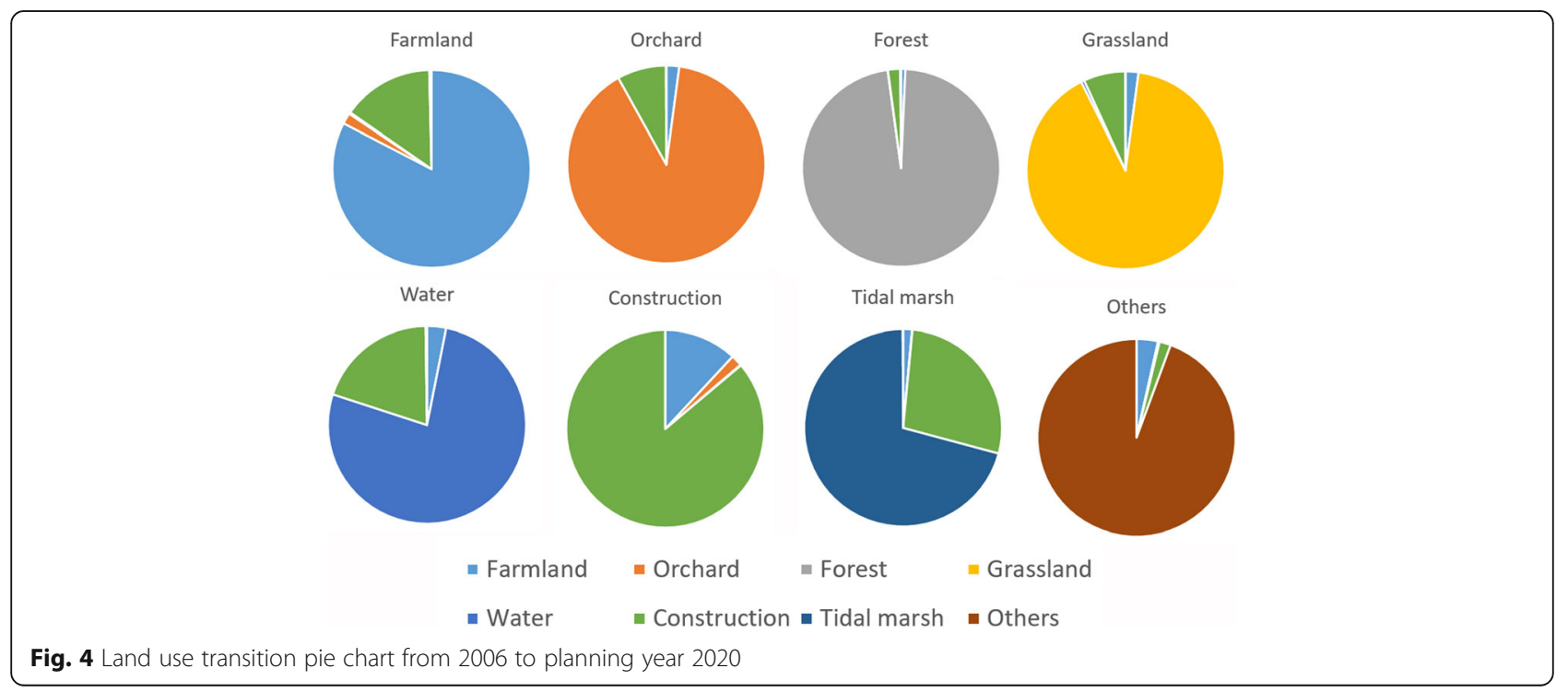


Table 7 Changes in ecosystem service values in the Dinghai District (unit; million Chinese yuan/year)

\begin{tabular}{|c|c|c|c|c|c|c|c|c|c|}
\hline \multirow[t]{2}{*}{ Land use } & \multicolumn{2}{|l|}{2006} & \multicolumn{2}{|l|}{2012} & \multicolumn{2}{|l|}{2020} & \multicolumn{3}{|c|}{ Changes in ESV } \\
\hline & ESV & ESV (\%) & ESV & ESV (\%) & ESV & ESV (\%) & 2006-2012 & 2012-2020 & 2006-2020 \\
\hline Farmland & 184.7 & 11.25 & 164.7 & 10.41 & 167.1 & 10.77 & -20.0 & 2.4 & -17.6 \\
\hline Orchard & 28.0 & 1.71 & 27.4 & 1.73 & 36.3 & 2.34 & -0.6 & 8.9 & 8.3 \\
\hline Forest & 949.0 & 57.79 & 964.7 & 60.95 & 922.2 & 59.42 & 15.7 & -42.5 & -26.8 \\
\hline Grassland & 9.9 & 0.60 & 5.0 & 0.31 & 9.0 & 0.58 & -4.9 & 4.0 & -0.9 \\
\hline Water & 169.5 & 10.32 & 146.8 & 9.27 & 134.1 & 8.64 & -22.7 & -12.7 & -35.3 \\
\hline Construction & 88.6 & 5.39 & 123.4 & 7.79 & 127.7 & 8.23 & 34.8 & 4.3 & 39.1 \\
\hline Others & 18.6 & 1.13 & 20.2 & 1.28 & 18.4 & 1.19 & 1.7 & -1.8 & -0.1 \\
\hline Tidal marsh & 193.9 & 11.81 & 130.7 & 8.25 & 137.2 & 8.84 & -63.3 & 6.6 & -56.7 \\
\hline Total & 1642.1 & 100 & 1582.8 & 100 & 1552.0 & 100 & -59.3 & -30.9 & -90.2 \\
\hline
\end{tabular}

\section{Ecosystem sensitivity analysis}

In order for the results to be reliable, the sensitivity of ESV to changes in the value coefficients must be relatively low $(C S<1)$. The percentage change in the estimated total ESV and the corresponding coefficient of sensitivity (CS), resulting from a $50 \%$ adjustment in the service value coefficient ( $\mathrm{VC})$, indicated that the total ESV values were relatively inelastic with respect to changes in the value coefficients (Table 9). The coefficient of sensitivity for the forest land use type was 0.61 , the highest among all land uses, due to its relatively large area and high value coefficient. Overall, the sensitivity analysis indicated that the ESV estimation in the study area was robust despite uncertainties in the value coefficients.

\section{Discussion}

Due to the fact that the ESV of forests planted for 1 year and virgin forests is different, this paper ignored these differences in land use types. As discussed in previous research, these results are coarse considering the deviations and uncertainties caused by the complex, dynamic, and nonlinear interactions among different ecosystem components (Limburg et al. 2002; Turner et al. 2003) and the limitations of economic valuation (Costanza et al. 1997b). However, it is important to recognize that accurate coefficients are often less critical for time series because coefficients tend to affect estimates of directional change. This study primarily focused on changes in ecosystem services over time. The coefficient of sensitivity in this study was less than 1 for a variety of land use types, suggesting validity of the response of ESV to land use change and planning.

As demonstrated in Table 6, construction land would have used $78 \%$ of its planned quota in 6 years, implying that the plan was unreasonable and/or would not meet development needs. From 2006 to 2012, most of the lost farmlands were replaced by construction land. In line with the idea that urbanization is becoming an important factor in land use change (Olaniyi et al. 2012), the impervious surface area (ISA) on the Zhoushan Archipelago increased significantly from 2006 to 2011 (Zhang et al. 2013) as a result of urban construction and the development of transportation infrastructure. Zhang et al. (2014) examined the coastline changes of the Zhoushan Archipelago and found noteworthy seaward

Table 8 Values of ecosystem service functions (unit; million Chinese yuan/year)

\begin{tabular}{|c|c|c|c|c|c|c|c|}
\hline & & \multicolumn{2}{|l|}{2006} & \multicolumn{2}{|l|}{2012} & \multicolumn{2}{|l|}{2020} \\
\hline & & ESV & ESV (\%) & ESV & ESV (\%) & ESV & ESV (\%) \\
\hline \multirow[t]{2}{*}{ Providing services } & Food production & 39.9 & 2.43 & 36.7 & 2.32 & 36.8 & 2.37 \\
\hline & Raw material & 115.5 & 7.03 & 115.6 & 7.30 & 112.0 & 7.22 \\
\hline \multirow[t]{4}{*}{ Regulating services } & Gas regulation & 190.8 & 11.62 & 192.0 & 12.13 & 187.8 & 12.10 \\
\hline & Climate regulation & 233.9 & 14.24 & 220.7 & 13.94 & 217.9 & 14.04 \\
\hline & Hydrological regulation & 297.8 & 18.13 & 279.4 & 17.65 & 272.0 & 17.53 \\
\hline & Waste treatment & 213.4 & 12.99 & 190.6 & 12.04 & 187.5 & 12.08 \\
\hline \multirow[t]{2}{*}{ Supporting services } & Soil maintenance & 199.0 & 12.12 & 198.7 & 12.55 & 195.4 & 12.59 \\
\hline & Biodiversity maintenance & 223.3 & 13.60 & 221.6 & 14.00 & 216.9 & 13.97 \\
\hline Cultural services & Aesthetic landscape & 128.6 & 7.83 & 127.6 & 8.06 & 125.6 & 8.09 \\
\hline Total & & 1642.1 & 100 & 1582.8 & 100 & 1552.0 & 100 \\
\hline
\end{tabular}


Table 9 Percentage changes in estimated ESV and CS resulting from a $50 \%$ adjustment in VC

\begin{tabular}{|c|c|c|c|c|c|c|}
\hline \multirow{2}{*}{$\begin{array}{l}\text { Change of value } \\
\text { coefficient }\end{array}$} & \multicolumn{2}{|l|}{2006} & \multicolumn{2}{|l|}{2012} & \multicolumn{2}{|l|}{2020} \\
\hline & $\%$ & CS & $\%$ & CS & $\%$ & CS \\
\hline Farmland VC $\pm 50 \%$ & 5.62 & 0.1125 & 5.20 & 0.1041 & 5.38 & 0.1077 \\
\hline Orchard VC $\pm 50 \%$ & 0.85 & 0.0171 & 0.87 & 0.0173 & 1.17 & 0.0234 \\
\hline Forest $\mathrm{VC} \pm 50 \%$ & 28.89 & 0.5779 & 30.47 & 0.6095 & 29.71 & 0.5942 \\
\hline Grassland VC $\pm 50 \%$ & 0.30 & 0.0060 & 0.16 & 0.0031 & 0.29 & 0.0058 \\
\hline Water VC $\pm 50 \%$ & 5.16 & 0.1032 & 4.64 & 0.0927 & 4.32 & 0.0864 \\
\hline Construction VC $\pm 50 \%$ & 2.70 & 0.0539 & 3.90 & 0.0779 & 4.11 & 0.0823 \\
\hline Others VC $\pm 50 \%$ & 0.56 & 0.0113 & 0.64 & 0.0128 & 0.59 & 0.0119 \\
\hline Tidal marsh VC $\pm 50 \%$ & 5.90 & 0.1181 & 4.13 & 0.0825 & 4.42 & 0.0884 \\
\hline
\end{tabular}

expansion during the past four decades. This suggests that local governments should strictly implement the principle of "Farmland Requisition-Compensation Balance" as stated in the "General Land Use Planning in Dinghai District of Zhoushan City (2006-2020).”

The farmland of the Zhoushan Archipelago is very limited, and according to the "Overall Planning of Zhoushan Archipelago New Area (city), Zhejiang (20122030)," the construction land and the farmland in the New Area are highly colocated spatially. We can predict that with the rapid development of the Zhoushan Archipelago, the conflicts between development and ecological protection will continue to intensify. Accordingly, the government should adjust land use planning to ease the competition for green space. The amount of construction land area per capita found in a 2006 study was $197.1 \mathrm{~m}^{2} /$ person (the population then was 0.3733 million); by 2012, the construction land area per capita had grown to $268.8 \mathrm{~m}^{2} /$ person (the population was 0.3812 million). This means that the government should improve construction land use intensity rather than expanding construction area. Furthermore, the government would benefit to pay more attention to the construction of urban and public green to improve the ESV of construction land, and realize the coordinated development of land use demand and ecological protection.

As a special marine ecosystem, the Dinghai District has unique characteristics from the perspective of ecological processes, structure, and functions. As in the case study by Zhao et al. (2004), which pointed out that the wetlands and tidal flats of Chongming Island are valuable yet rapidly decreasing land resources due to largescale ocean reclamation activities, this study suggests that the Zhoushan Archipelago is facing the same problem: its tidal marsh is declining quickly. The reclaimed areas have mostly been used for road construction, urban buildings, and basic infrastructures, reducing the buffer between land and ocean. Reclamation of these sensitive buffer zones or shores significantly altered the ecological properties and shortened the distance between human dwellings and marine systems, and thus their associated ESV. What is more, ocean and coastal tourism mounts significant pressure for the local

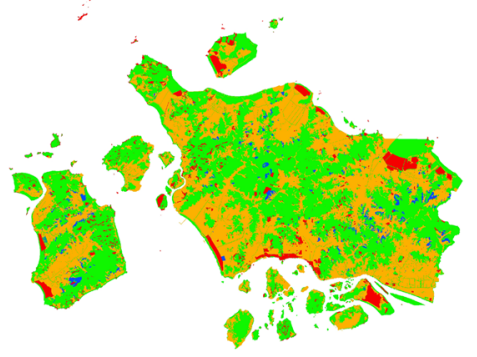

2006

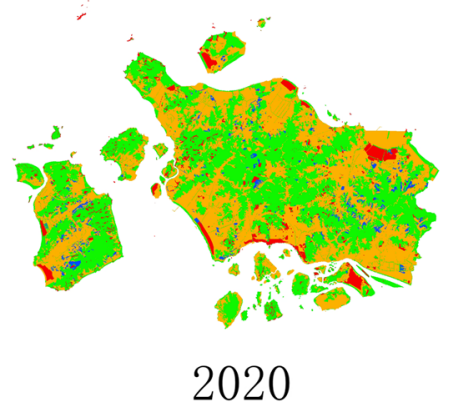

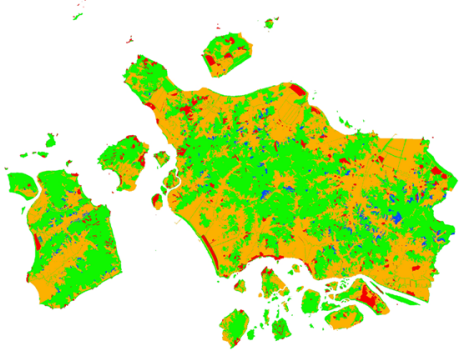

2012

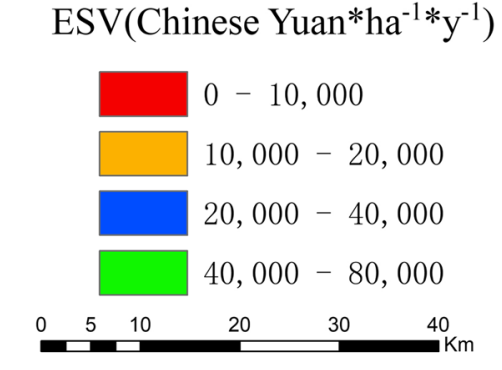

Fig. 5 Spatial distribution of the ESV values in the Dinghai District in 2006, 2012, and the planned year 2020 
environment (Hall 2001), as the tourist numbers of Dinghai District increased from 2.01 million in 2006 to 5.45 million in 2012. Management strategies for coastal and ocean tourism need to be developed.

Quantifying services provided by land use in the form of money is the direct embodiment of the optimization of regional land resources. From 2006 to 2012, the ESV of forest, construction land, and the others category increased, among which the construction land increased the most. From 2006 to 2020, only orchard and construction land ESV grew, while the others land types decreased, especially the water, forest and tidal marsh. Generally speaking, from 2006 to 2012, the total ESV declined a lot, and when it comes to the planned year 2020, the total ESV further decreased. Therefore, the government of Dinghai District should give more consideration to ecological protection, especially in the forest, tidal marsh, farmland, and water areas that have a large impact on the total ESV values. We suggest that better controlling urban growth would ensure greater ecological sustainability.

Based on the analysis of the composition of ecosystem service functions, it was clear that the contributions to the total ESV were (from high to low) hydrological regulation, climate regulation, biodiversity, soil conservation, greenhouse gas regulation, waste treatment, aesthetic landscape provision, raw material supplies, and food production. Because of the accelerated urbanization, with the exception of a slight increase in ESV from greenhouse gas regulations and raw material supplies, all other service functions were reduced from 2006 to 2012. The results from this study suggested that the Zhoushan Archipelago is facing the mounting pressure of rapid urbanization, similar to the case study in Xiamen, a coastal city in China (Lin et al. 2013). Integrating traditional knowledge and scientific knowledge for coastal management can be used to alleviate this pressure (Cicin-Sain 1993; Abreu et al. 2017).

\section{Conclusions}

By quantitatively analyzing the impacts of land use change on ESV in the Dinghai District of Zhoushan Archipelago from 2006 to 2012 and the planned year 2020, the following conclusions were reached: (1) from 2006 to 2012, there were significant changes in land use in the district, especially in the construction land, farmland, and tidal marsh categories. Furthermore, most of the farmland and tidal marsh were replaced by construction land of low ecological values; (2) The total ESV of the district decreased significantly due to land use changes by $59.3 \mathrm{M}$ from 2006 to 2012 and by an additional 30.9 M Chinese yuan by year 2020; (3) In terms of dominance, more than $55 \%$ of the total ESV was comprised of forest, followed by farmland, water, and tidal marsh with grassland being the least; (4) The ecosystem service functions of the Dinghai District were mainly related to hydrological regulation, biodiversity, waste treatment, and climate regulation, contributing more than $55 \%$ of the total ESV, with food production as the least significant contributor.

In conclusion, the planned land use by 2020 seems unsustainable for the Zhoushan Archipelago, and the local government may need to adjust the current plan to reduce the conflict over space by strictly implementing the Farmland Requisition-Compensation Balance policy and improving land use efficiency. At the same time, the government should also give more considerations to ecological protection, especially the forest, tidal marsh, farmland, and water surface areas because of their large impacts on the total ESV.

\section{Acknowledgements \\ The authors would like to thank all the participants who were involved in fieldwork.}

\section{Funding}

This research was financially supported by the National One-Thousand-Talent Program, the National Natural Science Foundation of China (no. 41401404). Preparation of this manuscript was partially supported by the Fundamental Research Funds for the Central Universities (2015QNA4039) and the Asian Pacific Network funded project (ARCP2013-FP25-Wu).

\section{Publisher's Note}

Springer Nature remains neutral with regard to jurisdictional claims in published maps and institutional affiliations.

\section{Authors' contributions}

JQ and CJ designed the study. LQ and CX helped in collecting the data. SX and JJ analyzed the data. SX, JC, and QJ wrote the manuscript. All authors read and approved the final manuscript.

\section{Competing interests}

The authors declare that they have no competing interests.

Received: 22 April 2017 Accepted: 30 June 2017

Published online: 03 August 2017

\footnotetext{
References

Abreu JS, Domit C, Zappes CA (2017) Is there dialogue between researchers and traditional community members? The importance of integration between traditional knowledge and scientific knowledge to coastal management. Ocean Coast Manag 141:10-19

Badola R, Barthwal S, Hussain SA (2012) Attitudes of local communities towards conservation of mangrove forests: a case study from the east coast of India. Estuar Coast Shelf Sci 96(1):188-196

Brenner J, Jiménez JA, Sardá R et al (2010) An assessment of the non-market value of the ecosystem services provided by the Catalan coastal zone, Spain. Ocean \& Coastal Management 53(1):27-38

Chen, J, Zhan, Y, Mao, Z (2009). Land-cover change and its time-series reconstructed using remotely sensed imageries in the Zhoushan islands. Proceedings of SPIE - The International Society for Optical Engineering, 7478

Cicin-Sain B (1993) Sustainable development and integrated coastal management. Ocean Coast Manag 21(1-3):11-43

Costanza R, D'Arge R, Groot RD et al. (1997a) The value of the world's ecosystem services and natural capital. Ecol Econ 387:253-260.

Costanza R, Cumberland J, Daly H et al (1997b) An introduction to ecological economics. St Lucie Press, FL, USA

Daily GC (1977) Nature's services: societal dependence on nature ecosystems. Island Press, Washington
} 
Estoque RC, Murayama Y (2013) Landscape pattern and ecosystem service value changes: implications for environmental sustainability planning for the rapidly urbanizing summer capital of the Philippines. Landsc Urban Plan 116(4):60-72

Feng Y, He C, Yang Q, et al. (2014). Evaluation of ecological effect in land use planning using ecosystem service value method. Nongye Gongcheng Xuebao/transactions of the Chinese Society of Agricultural Engineering, 30(9):201-211

Hall CM (2001) Trends in ocean and coastal tourism: the end of the last frontier? Ocean Coast Manag 44(9-10):601-618

HU H, Liu H, Hao J (2013) Spatio-temporal variation in the value of ecosystem services and its response to land use intensity in an urbanized watershed. Acta Ecol Sin 33(8):2565-2576

Kreuter UP, Harris HG, Matlock MD et al (2001) Change in ecosystem service values in the San Antonio area, Texas. Ecol Econ 39(3):333-346

Kumar CS, Sarada DVL, Gideon TP et al (2008) Antibacterial activity of three South Indian seagrasses, Cymodocea serrulata, Halophila ovalis, and Zostera capensis. World J Microbiol Biotechnol 24(9):1989-1992

Li T, Li W, Qian Z (2010) Variations in ecosystem service value in response to land use changes in Shenzhen. Ecol Econ 69(7):1427-1435

Limburg KE, O' Neill RV, Costanza R, Farber S (2002) Complex systems and valuation. Ecol Econ 41:409-420

Lin T, Shi L, Xue X et al (2013) Urban spatial expansion and its impacts on island ecosystem services and landscape pattern: a case study of the island city of Xiamen, Southeast China. Ocean Coast Manag 81(9):90-96

Liu JY, Liu ML, Zhuang DF et al (2002) Analysis of spatial pattern of land use change in China in recent years. Science China 32(12):1031-1040, in Chinese

Mann ML, Kaufmann RK, Bauer DM et al (2013) Ecosystem service value and agricultural conversion in the Amazon: implications for policy intervention. Environ Resour Econ 53(2):279-295

Millennium Ecosystem Assessment (2003) Ecosystems and human well-being: a framework for assessment. Island Press, Washington

Moberg F, Rönnbäck P (2003) Ecosystem services of the tropical seascape: interactions, substitutions and restoration. Ocean Coast Manag 46(1-2):27-46

Olaniyi AO, Abdullah AM, Ramli MF, Alias MS (2012) Assessment of drivers of coastal land use change in malaysia. Ocean Coast Manag 67(10):113-123

Pattanayak SK (2004) Valuing watershed services: concepts and empirics from southeast Asia. Agr Ecosyst Environ 104(1):171-184

People's Government of Dinghai District (2010) General land use planning in Dinghai District of Zhoushan City., pp 2006-2020

People's Government of Zhejiang Province (2013) Overall planning of Zhoushan Archipelago New Area (city), Zhejiang., pp 2012-2030

Shi HH, Zheng W, Ding DW et al. (2009) Valuation and ecosystem services of typical island. Mar Environ Sci 28(6):743-748.

Speziale L, Geneletti D (2014) Applying an ecosystem services approach to support land-use planning: a case study in Koboko district, Uganda. Ecol Process 3(1):1-13

State Administration of Grain. 2014 China Grain Yearbook. Economic Management Press, 2014

Turner RK, van den Bergh JCJM, Söderqvist T et al (2000) Ecological-economic analysis of wetlands: scientific integration for management and policy. Ecol Econ 35(1):7-23

Turner RK, Paavola J, Coopera P et al (2003) Valuing nature: lessons learned and future research directions. Ecol Econ 46:493-510

Wang Y, Gao J, Wang J, Qiu J (2014) Value assessment of ecosystem services in nature reserves in Ningxia, China: a response to ecological restoration. PLoS One 9(2):e89174

Wang Z, Wang Z, Zhang B et al (2015) Impact of land use/land cover changes on ecosystem services in the Nenjiang River Basin, Northeast China. Ecol Process 4(1):11

Westman WE (1977) How much are nature's services worth? Science 197(4307):960-4

Xie GD, Lu CX, Cheng SK (2001) Progress in evaluating the global ecosystem services. Resources Science 23(6):5-9 (in Chinese)

Xie GD, Lin Z, Chun-Xia LU et al (2008) Expert knowledge based valuation method of ecosystem services in China. J Nat Resour 23(5):911-919

Xie GD, Lu CX, Leng YF et al (2003) Ecological assets valuation of the Tibetan Plateau. J Nat Resour 18:189-196 (in Chinese)

Xu XU, Xiao-Bing LI, Na FU et al. (2008) Application of ecosystem services valuation in strategic environmental assessment for land-use planning in Beijing. Resources Science 30(9):1382-1388.
Zhang X, Pan D, Chen J et al (2013) Using long time series of Landsat data to monitor impervious surface dynamics: a case study in the Zhoushan Islands. J Appl Remote Sens 7(7):1268-1268

Zhang X, Pan D, Chen J et al (2014) Evaluation of coastline changes under human intervention using multi-temporal high-resolution images: a case study of the Zhoushan Islands, China. Remote Sens (Basel) 6(10):9930-9950

Zhao B, Kreuter U, Li B et al (2004) An ecosystem service value assessment of land-use change on Chongming Island, China. Land Use Policy 21(2):139-148

Zhao J, Shen G, Yan LJ et al (2016) Assessment and spatiotemporal analysis of the ecosystem services value of island: a case study of Jintang Island. Acta Ecol Sin 36(23):7768-7777

Zhao J, Xiao H, Wu G (2000) Comparison analysis on physical and value assessment methods for ecosystems services. Chin J Appl Ecol 11(2):290-292

Zhao S, Li MN, Wu CW (2014) Emergy valuation of ecosystem services in the zhoushan marine area. Langmuir the Acs Journal of Surfaces \& Colloids 29(50):15655-15663

Zhou J, Chen Y, Xiao J, Li Y (2004) Dynamic assessment of ecosystem service value: a case study of Xiangfan, Hubei Province after the project of south to north water transfer project in China. Acta Ecol Sin 24(4):743-749.

\section{Submit your manuscript to a SpringerOpen ${ }^{\circ}$ journal and benefit from:}

- Convenient online submission

- Rigorous peer review

- Open access: articles freely available online

- High visibility within the field

- Retaining the copyright to your article

Submit your next manuscript at $>$ springeropen.com 